\title{
The Migration of Kirschner Wire from Left Distal Clavicle to the Intradural Anterior Thoracic Spine
}

\author{
Douglas Gonsales $^{1 *}$, Pedro Aguilar-Salinas ${ }^{1}$, Alessandro Cavicchioli ${ }^{3}$, Thiago Albonete Felício ${ }^{2}$, Felipe Bastos \\ Lima $^{2}$ and Nicandro Figueiredo ${ }^{3}$
}

${ }^{1}$ Neurosurgery department, Baptist Medical Center, USA

${ }^{2}$ Neurosurgery, University General Hospital, Brazil

${ }^{3}$ Department of Neurosurgery, University General Hospital, Brazil

Submission: January 03, 2017; Published: February 20, 2017

*Corresponding author: Douglas Gonsales, Neurosurgery department, Baptist Medical Center, USA, Email: gonsalesdouglas@gmail.com

\begin{abstract}
We report a 42 year old man who had undergone osteo synthesis to treat left clavicle fracture with a Kirschner wires (K-wire). After 1 month of surgery, began to feel pain in left clavicle region. He was informed that the symptom was expected by the surgical procedure and just analgesics were prescribed. Three months after surgery the pain in left clavicle and upper thoracic spine region continue and an $\mathrm{x}$-ray shows the K-wire had migrated medially. It was attempted to remove with locally anesthetic, but unsuccessfully.

Thoracic spine CT scan showed the wire in the T2-T3 level of the spinal canal. No sensory or motor disability. There was submitted a surgical procedure with a right lateral trans-thoracic approach with elevation of the scapula to remove the wire around $105 \mathrm{~mm}$ of length successfully. The 6 months of follow-up were neurologically asymptomatic.
\end{abstract}

Keywords: Kirschner wire migration; Clavicular fracture; Thoracic spine

\section{Introduction}

Surgical Procedure to the clavicle fracture is incomum. It just accepted to unstable fracture that can be treated surgically with plates, pins or wires [1]. Kirschner wires (K-wire) are simple tools to manage some fractures. A notable concern is the potential for these devices to migrate to distant anatomic sites. Migration of $\mathrm{K}$-wires used for fixation of the clavicle fracture into the thoracic cavity or thoracic and cervical spine is a rare but serious complication, including lethal cardiovascular events [2-16]. Migration of K-wire to the another cavity (thoracic, mediastinum and spine) is refer with a neurologic symptom. There are a few cases and it has been reported since 1943 [16,17]. It was found just one case report with asymptomatic spinal migration [18]. The symptom are sensitive disability, horner's syndrome, diplopia, headache, subarachnoid hemorrhage, sporadically arachnoiditis [19,20] and Brown-Sequard syndrome [21]. The follow-up of K-wire fixation is recommendated and whether observed signal of migration it will be necessary to be remove immediately [22,23].

\section{Case Report}

A 42 year old man has been involved in a motorcycle accident presenting with fractured of his left clavicle, and underwent of k-wire fixation. He came to the emergency department complaining of back pain some days after the procedure. After 1 month of the surgery, began to feel pain in the left clavicle region treated with just an analgesics. Three months after surgery a pain in the left clavicle and upper thoracic spine region continue and an x-ray were obtained showing an osteosynthesis device had migrated medially to the spinal. Simple removing were attempted unsuccessfully. Physical examination shows a surgical scar on the left clavicle region and pain at the palpation of the thoracic spine and with a high mobilization of the trunk. No neurological symptoms were observed.

Thoracic spine CT scan which showed a foreign body in the spinal canal at the T2-T3 level (Figure 1\&2). Left lateral trans-thoracic with elevation of the scapula approach with visualization of the heart, spine and lung (Figure 3) were 
performed to remove the K-wire. Immediate post procedural were in the intensive care unit with a chest drain (Figure 4) with no neurological symptoms. The chest drain were removed in 48 hours. The 6 months follow-up has observed no neurological symptoms.

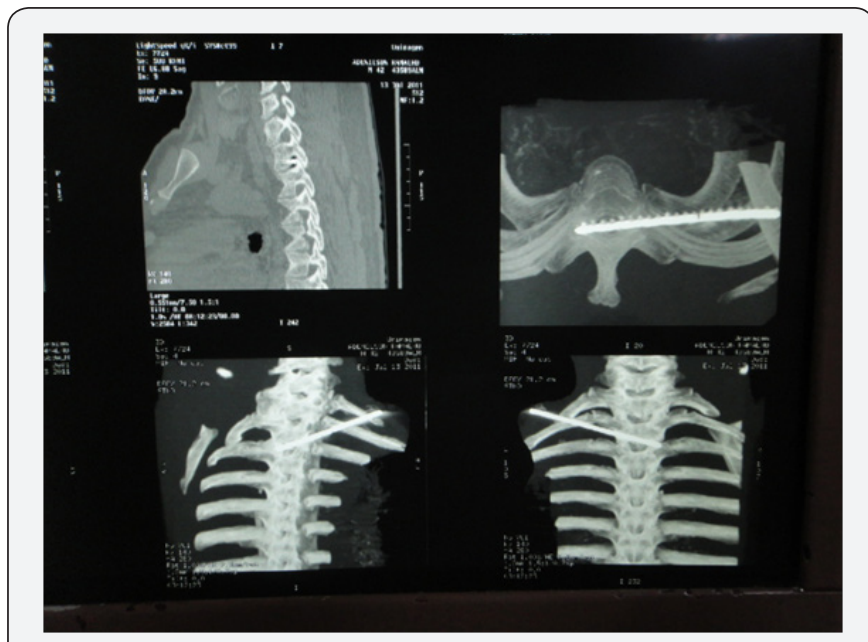

Figure 1: Computed Tomography (CT) of the Thoracic spine shows the wire penetrating in the left T2-T3 vertebral canal.

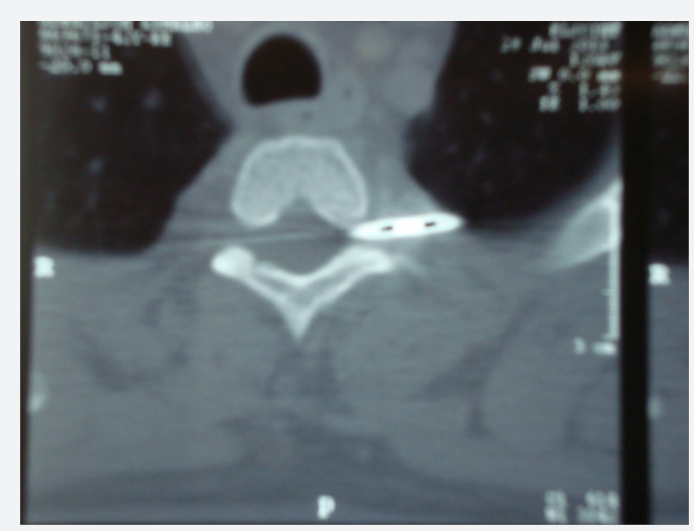

Figure 2: Computed Tomography (CT) of the Thoracic spine shows the wire penetrating into the left intervertebral forame.

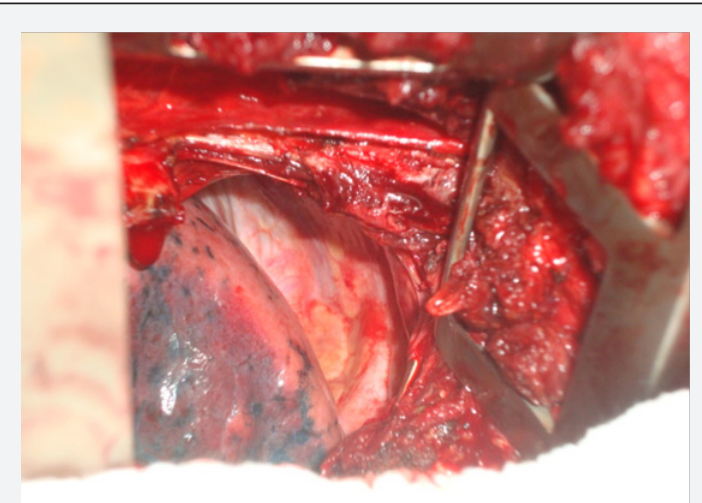

Figure 3: Intraprocedure image showing the intercostal space opened. Visualization of the intrathoracic cavity, lung and the wire.

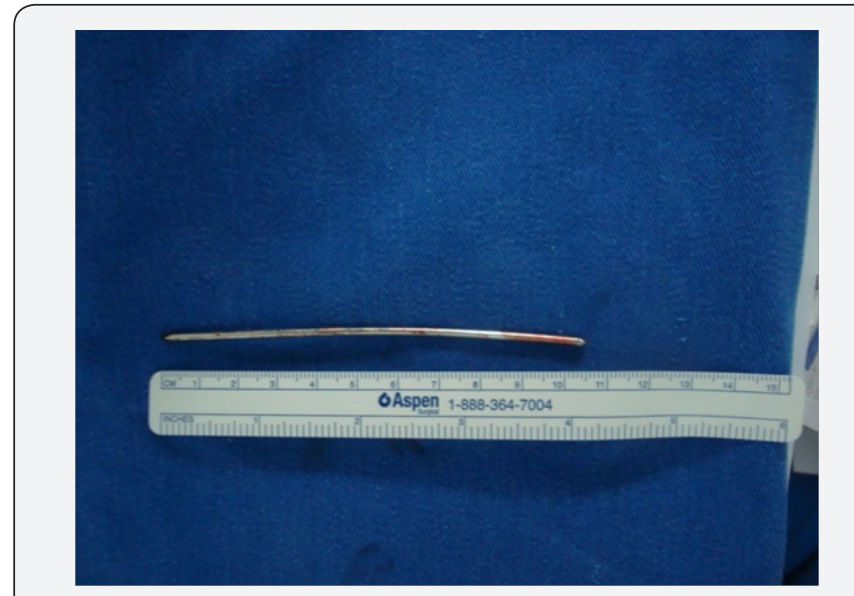

Figure 4: The migrated wire removed of $105 \mathrm{~mm}$.

\section{Discussion}

Migration of the osteosynthetic device with penetration into the spinal canal is rare but it is a well-known complication since the first report in 1943 [17], and the infection is the most common complication. The spinal canal migrating site are more frequently to thoracic, mediastinum, abdome, heart, pelvis, liver [4,24-26] and occur frequently when use the no bending technique. Distant migrations of K-wires have been reported, for example, from the finger to the heart, pelvis to the abdomen, pelvis to the heart, and hip to the liver [25,27-29]. The diagnostic were necessary a good physical examination, complete neurologic examination, and the work-up with x-ray, CT. K-wire migration from the shoulder into the abdomen can compromise the spleen [12] abdominal aortic lumen [30] the neck and spine $[14,16]$.

The most commonly migrating site from the shoulder region are the chest wall with invasion of the thorax, ending up in the pleural space [31], pulmonary parenchyma [8] mediastinum [5], esophagus [3], cavities, pericardial space, subclavian artery, ascending aortic wall or pulmonary artery and this migration can result in serious complications, including lethal cardiovascular events $[9,10,32]$. Once the correct diagnosis has been made the surgical remove were obligatory. There are no consensus regarding the best surgical technique.

It was decided by left lateral trans-thoracic surgical approach with elevation of the scapula, pulling the rib greatly facilitating the visualization of the entire thoracic cavity and complete access to the K-wire near the T2 vertebra. Several methods to prevent or promptly detect such migration have been devised. Patients undergoing wire osteo synthesis should receive regular plain radiographic follow-up after a complete instruction of the complications possibilities. However, threaded wires cannot completely eliminate the possibility of migration [33] even after years of being firmly in place. It is recommended that patients with K-wires are monitored and that if any sign of moving these wires should be removed mainly before symptoms $[22,23]$. 


\section{Open Access Journal of Neurology \& Neurosurgery}

\section{References}

1. Anderson K (1987) Treatment of clavicular fractures. Acta Orthop Scan 8: 58-71.

2. Medved I, Simic O, Bralic M, et al. (2006) Chronic heart perforation with $13.5 \mathrm{~cm}$ long Kirschner wire without pericardial tamponade: an unusual sequelae after shoulder fracture. Ann Thorac Surg 81(5):18951897.

3. Wada S, Noguchi T, Hashimoto T, Uchida Y, Kawahara K (2005) Successful treatment of a patient with penetrating injury of the esophagus and brachiocephalic artery due to migration of Kirschner wires. Ann Thorac Cardiovasc Surg 11(5): 313-315.

4. Chou NS, Wu MH, Chan CS, Lai WW, Lin MY (1994) Intra thoracic migration of Kirschner wires. J Formos Med Assoc 93(11-12): 974-976.

5. Leppilahti J, Jalovaara P (1999) Migration of Kirschner wires following fixation of the clavicle: a report of 2 cases. Acta Orthop Scand 70(5): 517-526.

6. Hopkinson-Woolley JA, Constant CR (1998) Fixation of fractures of the clavicle with Kirschner wires. J Bone Joint Surg Br 80: 746.

7. Bedi GS, Gill SS, Singh M, Lone GN (1997) Intra thoracic migration of a Kirschner wire: case report. J Trauma 43(5): 865-866.

8. Foster GT, Chetty KG, Mahutte K, Kim JB, Sasse SA (2001) Hemoptysis due to migration of a fractured Kirschner wire. Chest 119(4): 12851286.

9. Goodsett JR, Pahl AC, Glaspy JN, Schapira MM, et al. (1999) Kirschner wire embolization to the heart: an unusual cause of pericardial tamponade. Chest 115(1): 291-293.

10. Anic D, Brida V, Jelic I, Orlic D (1997) The cardiac migration of a Kirschner wire: a case report. Tex Heart Inst J 24(4): 359-361.

11. Daus GP, Drez D Jr, Newton BB Jr, Kober R (1993) Migration of a Kirschner wire from the sternum to the right ventricle: a case report. Am J Sports Med 21(2): 321-322.

12. Potter FA, Fiorini AJ, Knox J, Rajesh PB (1988) The migration of a Kirschner wire from shoulder to spleen: brief report. J Bone Joint Surg Br 70(2): 326-327.

13. Demaria R, Picard E, Bodino M, Aymard T, Albat B, et al. (1998) Migration of a clavicular bone wire acutely perforating the ascending aorta. Presse Med 27(21): 1013.

14. Mellado JM, Calmet J, Garcia Forcada IL, Sauri A, Gine J (2004) Early intrathoracic migration of Kirschner wires used for percutaneous osteosynthesis of a two-part humeral neck fracture: a case report. Emerg Radiol 11(1): 49-52.

15. Loncan LI, Sempere DF, Ajuria JE (1998) Brown-Sequard syndrome caused by a Kirschner wire as a complication of clavicular osteosynthesis. Spinal Cord 36(11): 797-799.

16. Priban V, Toufar P (2005) A spinal cord injury caused by a migrating Kirschner wire following osteosynthesis of the clavicle: a case review. Rozhl Chir 84(7): 373-375.
17. Mazet RJ (1943) Migration of a Kirschner-wire from the shoulder region into the lung: report of two cases. J Bone Joint Surg Am 25(2): 477-483.

18. Saad Bennis, Pietro Scarone, Stephan Gaillard (2008) Asymptomatic Spinal Canal Migration of Clavicular K Wire at the Cervicothoracic Junction. Orthopedics 31(12): 1129-1135.

19. Kida Y, Naritomi H, Sawada T, Kuriyama Y, Ogawa M, et al. (1988) Cervical spinal cord injury caused by acunpuncture. Arch Neurol 45(8): 831.

20. Kondo A, Koyama T, Ishikawa J, Yamasaki T (1979) Injury to the spinal cord produced by acunpuncture neddle. Surg Neurol 11(2): 155-156.

21. Loncan Li, Sempere DF, Ajuria JE (1998) Brown-Sequard syndrome caused by a Kirschner wire as a complication of clavicular osteosynthesis. Spinal Cord 36(11): 797-799.

22. Hinzpeter T, Sartor K (1977) The problem of material migration following osteosynthesis: penetration of a Kirschner wire into the spinal canal. ROFO Fortschr Geb Rontgenstr Nuklearmed 127(5): 493494.

23. Regel Jp, Pospiech J, Aalders TA, Ruchhotlzs (2002) Intra spinal migration of a Kirschner wire 3 months after clavicular fracture fixation. Neurosurg Rev 25(1-2): 110-112.

24. Haberneck H, Walch G (1989) Sekundare Drhtwanderung nach perkutaner Bohrdraht-Fixation einer Akromioklavikular luxation. Aktuel Traumatol 19: 218-220.

25. Fong YC, Lin WC, Hsu HC (2005) Intra pelvic migration of a Kirschner wire. J Chin Med Assoc 68(2): 96-98.

26. Marya KM, Yadav V, Rattan KN, Kundu ZS, Sangwan SS (2006) Unusual K-wire migration. Indian J Pediatr 73(12): 1107-1108.

27. Haapaniemi TA, Hermansson US (1997) Cardiac arrhythmia caused by a Kirschner wire inside the heart: an unusual complication of finger osteosynthesis. J Hand Surg Br 22(3): 402-404.

28. Fong YC, Lin WC, Hsu HC (2005) Intra pelvic migration of a Kirschner wire. J Chin Med Assoc 68(2): 96-98.

29. McCardel BR, Dahners LE, Renner JB (1989) Kirschner wire migration from the pelvis to the heart and a new method of fixation of articular fracture fragments, acetabular reconstruction. J Orthop Trauma 3(3): 257-259.

30. Naidoo P (1991) Migration of a Kirschner wire from the clavicle into the abdominal aorta. Arch Emerg Med 8(4): 292-295.

31. Ullmer E, Bolliger CT, Soler M (1998) Pneumothorax or the end of a wire's journey. Respiration 65(2): 151.

32. Daus GP, Drez D Jr, Newton BB Jr, Kober R (1993) Migration of a Kirschner wire from the sternum to the right ventricle: a case report. Am J Sports Med 21(2): 321-322.

33. Kocialkowski A, Wallace WA (1990) Closed percutaneous K-wire stabilization for displaced fractures of the surgical neck of the humerus. Injury 21(4): 209-212. 
(C) (i) This work is licensed under Creative BY
This work is licensed under Creative
Commons Attribution 4.0 Licens

\section{Your next submission with Juniper Publishers will reach you the below assets}

- Quality Editorial service

- Swift Peer Review

- Reprints availability

- E-prints Service

- Manuscript Podcast for convenient understanding

- Global attainment for your research

- Manuscript accessibility in different formats ( Pdf, E-pub, Full Text, Audio)

- Unceasing customer service

Track the below URL for one-step submission https://juniperpublishers.com/online-submission.php 